\title{
Drivers of the Low Metabolic Rates of Seagrass Meadows in the Red Sea
}

\author{
Andrea Anton ${ }^{1,2 *}$, Kimberlee Baldry ${ }^{1,2,3}$, Darren J. Coker ${ }^{1}$ and Carlos M. Duarte ${ }^{1,2}$ \\ ${ }^{1}$ Red Sea Research Center, King Abdullah University of Science and Technology, Thuwal, Saudi Arabia, ${ }^{2}$ Computational \\ Bioscience Research Center, King Abdullah University of Science and Technology, Thuwal, Saudi Arabia, ${ }^{3}$ Institute of Marine \\ and Antarctic Studies, University of Tasmania, Hobart, TAS, Australia
}

\section{OPEN ACCESS}

Edited by:

Stelios Katsanevakis,

University of the Aegean, Greece

Reviewed by:

Craig A. Layman,

North Carolina State University,

United States

Kasper Elgetti Brodersen,

University of Copenhagen, Denmark

Nadine Schubert,

University of Algarve, Portugal

Zhijian Jiang,

South China Sea Institute

of Oceanology (CAS), China

*Correspondence:

Andrea Anton

andrea.antongamazo@kaust.edu.sa

Specialty section:

This article was submitted to Marine Ecosystem Ecology,

a section of the journal

Frontiers in Marine Science

Received: 20 August 2019

Accepted: 30 January 2020

Published: 19 February 2020

Citation:

Anton A, Baldry K, Coker DJ and Duarte CM (2020) Drivers of the Low Metabolic Rates of Seagrass

Meadows in the Red Sea.

Front. Mar. Sci. 7:69.

doi: 10.3389/fmars.2020.00069
Tropical seagrass meadows are highly productive ecosystems that thrive in oligotrophic environments. The Red Sea is characterized by strong N-S latitudinal nutrient and temperature gradients, which constrain pelagic productivity. To date, the influence of these natural gradients have not been assessed in metabolic rates for local seagrass communities. Here we report metabolic rates [gross primary production (GPP), respiration (R), and net community production (NCP)] in four common species of seagrass (Halodule uninervis, Halophila ovalis, Halophila stipulacea, and Thalassia hemprichii) along latitudinal and thermal gradients in the Red Sea. In addition, we quantified leaf nutrient concentration (nitrogen, phosphorous, and iron), and correlate this with latitude. Our results show that average metabolic rates and aboveground biomass of seagrass meadows in the Red Sea were generally in the lower range when compared to global values reported for the same species elsewhere. The optimum temperature of Red Sea seagrass meadows varied among species with increases along the sequence: $H$. stipulacea $<T$. hemprichii $<H$. uninervis $\sim H$. ovalis. GPP for $\mathrm{H}$. uninervis - a seagrass thermophile - was lowest in higher latitudes and increased toward lower latitudes during the summer months. While temperature was identified as a strong driver of metabolic rates across seagrass meadows, leaf concentration of phosphorous and iron (but not nitrogen) was below nutrient sufficiency thresholds, indicating these two elements might be limiting for seagrass meadows in the Red Sea.

Keywords: iron, gross primary production, metabolic rates, nitrogen, nutrient limitation, phosphorous, thermal optima, thermal performance

\section{INTRODUCTION}

Seagrass meadows are found in shallow marine waters and are among the most productive ecosystems on Earth (Duarte and Chiscano, 1999). As such, they have the capacity to act as intense carbon sinks and therefore are a fundamental blue carbon habitat (Duarte et al., 2010; Fourqurean et al., 2012). Most of the regions occupied by seagrasses are located in shallow tropical waters, characterized by high light irradiance and temperature, and generally oligotrophic clear waters (Hemminga and Duarte, 2000). Therefore, tropical seagrass productivity is often controlled by the availability of nutrients (Duarte, 1990; Duarte et al., 1995; Agawin et al., 1996). In addition, the warm temperatures of tropical waters can play a key role in regulating the metabolism of seagrass meadows (Anton et al., 2009; Pedersen et al., 2016). Like many other marine organisms (Sibly et al., 2012; García et al., 2018; South et al., 2018), seagrass generally increase its metabolic rate [e.g., photosynthesis and respiration $(\mathrm{R})$ ] until reaching an optimum temperature beyond which they decline, sometimes abruptly (Marbà and Duarte, 2010). Similar to other marine coastal 
communities (O'Connor et al., 2009), the metabolic thermaldependence of seagrasses is often regulated by nutrient availability (Anton et al., 2011).

The Red Sea is the warmest sea in the world (Chaidez et al., 2017). It is characterized by strong north-south temperature and nutrient gradients, with higher nutrient concentrations and warmer waters toward the Southern region (Raitsos et al., 2013; Chaidez et al., 2017). These natural gradients render the Red Sea an optimal ecosystem to explore in situ drivers of seagrass productivity in tropical oligotrophic environments. Here seasonal changes in temperature have been identified as a strong driver of seagrass metabolism (Burkholz et al., 2019), as well as for the calcification rates in the common reef-building coral Pocillopora verrucosa (Sawall et al., 2015). Likewise, nutrient availability plays an important role for primary production in pelagic communities across the Rea Sea (López-Sandoval et al., 2019). A recent study suggests that iron limits macrophyte production, including seagrasses, in the Red Sea basin (Anton et al., 2018), but not conforming to a simple latitudinal gradient (e.g., iron limitation did not increase toward the northern Red Sea). Furthermore, iron limitation has been reported, and experimentally verified for the dominant mangrove species Avicennia marina in the central region (Almahasheer et al., 2016).

Despite being a hot spot for seagrass biodiversity, seagrasses within the Red Sea have been poorly studied (El Shaffai, 2011). Here seagrass meadows are commonly found in lagoons, on coastal shallow slopes, and around islands (Anton et al., 2018; Duarte et al., 2018). Knowledge of metabolic rates of seagrass meadows in this region is limited and has only been studied in two locations, the central Red Sea (Burkholz et al., 2019) and the Gulf of Aqaba in the north (Bednarz et al., 2015; Cardini et al., 2018). One recent study reports the metabolic rates of a meadow dominated by Enhalus acoroides, and a mixed meadow of Cymodocea serrulata and Halodule uninervis in a coastal lagoon in the central Red Sea (Burkholz et al., 2019). Two additional studies in the Gulf of Aqaba, a cooler and unique northern region, describe the gross primary- and net production of Halophila stipulacea (Bednarz et al., 2015; Cardini et al., 2018). A recent study assessing accumulation of organic carbon of five species of seagrasses in the Central Red Sea infers low net community production (NCP) rates and attributes this to the harsh environmental conditions, such as nutrient limitation and high temperature (Serrano et al., 2018). Yet, there is limited knowledge about how local environmental parameters influence metabolic rates of Red Sea seagrass meadows, and how this compares to global estimates.

Here we describe the community metabolism of seagrass meadows along a natural latitudinal gradient in the Red Sea and elucidate potential environmental drivers. Specifically, we (i) describe the metabolic rates (Gross Primary Production-GPP, R, and NCP) and the GPP/R of meadows of five seagrass species (H. uninervis, $H$. ovalis, $H$. stipulacea, Thalassia hemprichii, and Thalassodendron ciliatum) at eight locations along a latitudinal gradient (temperature and productivity) in the Red Sea, (ii) assess their community thermal performance and thermal sensitivity, and (iii) quantify how seagrass community metabolism relates to changes in nutrient composition (Nitrogen, Phosphorus, and Iron concentration) within seagrass leaves. We anticipate low metabolic rates for seagrass meadows in the Red Sea due to extremely oligotrophic nature of the basin. In addition, seagrass meadows in this region grow in carbonate-rich sediments, where phosphorous $(\mathrm{P})$ and iron $(\mathrm{Fe})$ are bound in unavailable forms. Therefore, we hypothesize that seagrass meadows in the Red Sea are likely to be $\mathrm{P}$ and Fe limited, and possibly also N.

\section{MATERIALS AND METHODS}

\section{Study Sites}

Eight seagrass meadows were surveyed along the Saudi Arabian coast of the Red Sea (from 18.23 to $27.30^{\circ} \mathrm{N}$; Figure 1 and Supplementary Table S1), during the winter (January-March) and summer (July-August) of 2017. Four locations

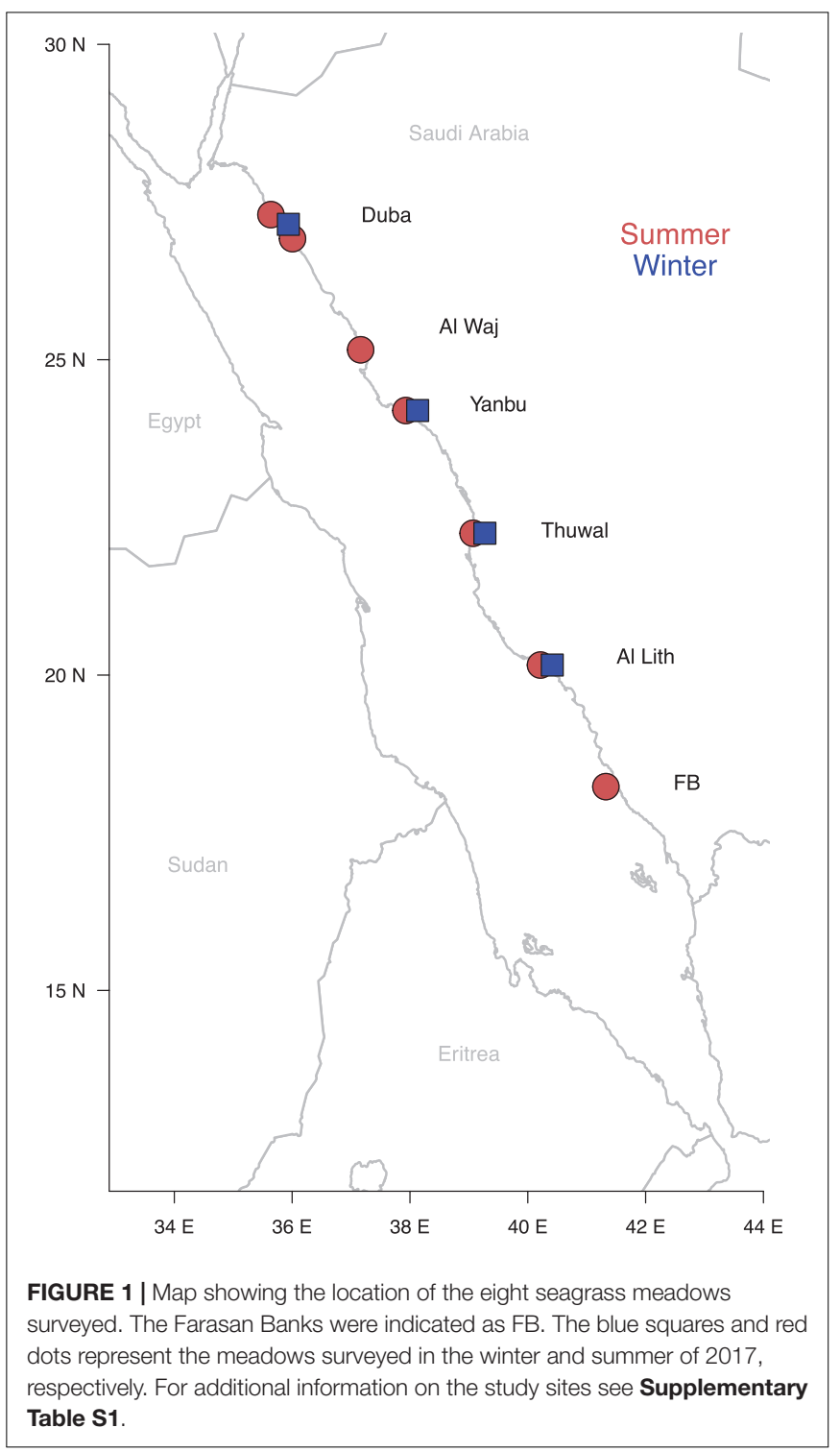


(Supplementary Table S1) were visited in the winter and six in the summer, with the Farasan Banks, the southernmost location, only visited in the summer. The meadows were between 0.5 and $7 \mathrm{~m}$ depth across a range of environmental conditions. Temperature and salinity were measured in situ using an Exosond CTD (YSI Inc., Yellow Springs, United States), while depth was assessed using a dive computer. Temperature increased southward ranging $23-27.4^{\circ} \mathrm{C}$ during the winter and $29.8-32.3^{\circ} \mathrm{C}$ during the summer. Salinity increased northward raging 38-40.2 and 38.2-40.2 in winter and summer, respectively (Supplementary Table S1). Seagrass species forming monospecific meadows (or large mono-specific patches within meadows) were surveyed at each location by snorkel or SCUBA (Figure 2). We evaluated five species of seagrasses (H. uninervis, $H$. ovalis, $H$. stipulacea, T. hemprichii, and T. ciliatum). Only a few seagrass meadow locations in the Red Sea were known before starting these surveys; therefore, meadows were surveyed as encountered, thereby producing a limited dataset. For instance, meadows of $T$. ciliatum were only encountered in the northern region during the summer. Subsequently, the data for T. ciliatum are only included in the manuscript as a preliminary reference for the Red Sea (Table 1 and Supplementary Tables S1, S2) but is not statistically analyzed or examined in the section "Discussion."

\section{Seagrass Meadow Metabolic Rates (GPP, R, NP), GPP/R Ratio, and Biomass}

Seagrass meadow metabolism was measured in three to four replicated hermetic, translucent cores $(9.5 \mathrm{~cm}$ diameter by $30.5 \mathrm{~cm}$ long) per species (Figure 2). Seagrass cores (which included the seagrass community and sediment) were randomly collected by hand in each meadow (Figure 2). Cores were placed into large incubators $(122 \times 50 \times 40 \mathrm{~cm})$ connected to a flow-through system using seawater from the study site. This maintained the in situ natural conditions of the meadow (e.g., temperature) during incubations. The following metabolic rates

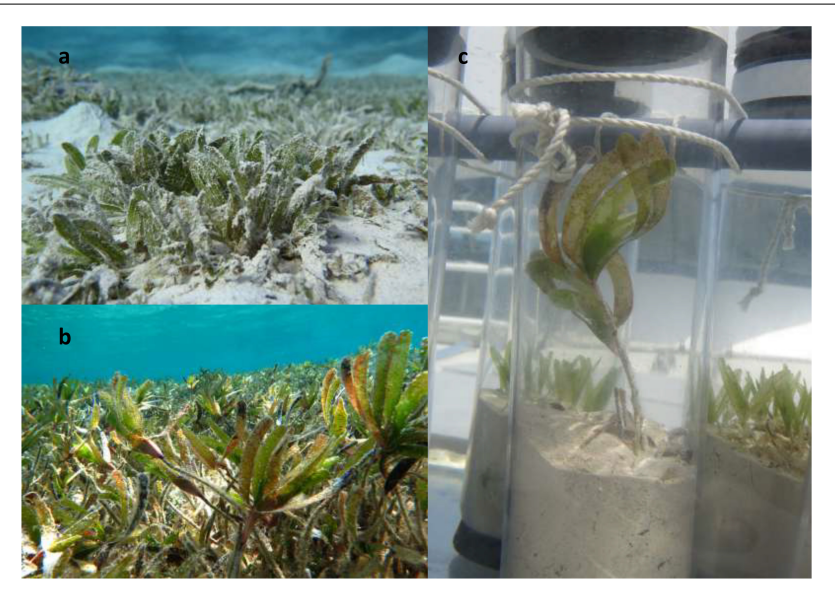

FIGURE 2 | Seagrass meadows of Halophila stipulacea (a) and Thalassodendron ciliatum (b) in the Red Sea. Close-up picture of the hermetically closed cores submerged in the incubation chambers (c). Photo credit: A. Anton. were assessed: GPP, R, and NCP. Additionally, we calculated the GPP/R ratio where values $>1$ and $<1$ indicate autotrophy and heterotrophy (e.g., the meadow is either a carbon sink or a carbon source, respectively). Cores were incubated for 3-4 h around midday (light) and at night (dark) with initial and final water oxygen concentrations recorded using a Fibox4 PreSens Oxygen Sensor (PreSens Precision Sensing, Germany). Sensors were brand new and did not required calibration. Before taking measurements with the probe, the water within the core was homogenized by mixing it gently. Oxygen concentration was assessed three times in different areas inside the core and then the average of these three aliquots was calculated for each measurement. Seagrass metabolic rates were calculated from the changes in oxygen concentration following Anton et al. (2011). NCP and R were calculated by the difference between the initial and final dissolved oxygen concentration in the clear dark incubations respectively. GPP was estimated as:

$$
\mathrm{GPP}=\mathrm{NCP}-\mathrm{R}
$$

Hourly rates were converted to daily rates by accounting for the light:dark hours per station and season, calculated using www.calculatorsoup.com. Daily rates were converted to surface units by taking into account the surface area of the core and the volume of water in the core.

At the end of the incubation, seagrass biomass in each core was assessed by rinsing the leaves of the seagrasses with seawater, gently removing the epiphytes, drying samples at $60^{\circ} \mathrm{C}$, and calculating the above ground biomass as: $\mathrm{g} \mathrm{DW} \mathrm{m}^{-2}$ (where $\mathrm{g}$ is grams and DW is dry weight).

\section{Optimum Temperature of Seagrass Meadows}

Metabolic thermal performance for seagrass meadows (e.g., GPP, $\mathrm{R}$, and NP) was quantified by fitting a four parameter SharpeSchoolfield equation (Padfield et al., 2017; García et al., 2018) along the thermal gradient for each species:

$$
\begin{gathered}
\ln (r(T))=E a_{\text {rise }}\left(1 / k T_{c}-1 / k T\right)+\ln \left(r\left(T_{c}\right)\right)-\ln (1+ \\
\left.e^{E h(1 / k T h-1 / k T)}\right)
\end{gathered}
$$

where $r(T)$ is the metabolic rate $\left(\mathrm{mmol} \mathrm{O} \mathrm{cm}^{-2} \mathrm{~h}^{-1}\right), k$ is the Boltzman's constant $\left(8.62 \times 10^{-5} \mathrm{eV} \mathrm{K}-1\right), E a_{\text {rise }}$ is the activation energy $(\mathrm{eV})$ up to a thermal optimum $\left(T_{o p t} ;{ }^{\circ} \mathrm{C}\right)$, $T$ is temperature $\left({ }^{\circ} \mathrm{K}\right), E_{h}$ characterizes temperature-induced inactivation of growth above $T_{h}$ - the temperature where half the enzymes are rendered non-functional - and $r\left(T_{c}\right)$ is the metabolic rate normalized to a reasonable reference temperature, $T_{c}=28^{\circ} \mathrm{C}$, where no low or high temperature inactivation is expected to be experienced. Equation 1 yields a maximum metabolic rate at an optimum temperature as follows:

$$
T_{o p t}=E_{h} T_{h} /\left(E_{h}+k T_{h} \ln \left(E_{h} / E_{a}-1\right)\right)
$$

Thermal performance curves were estimated for two species of seagrasses (H. stipulacea and T. hemprichii). For the other two 
TABLE 1 | Comparison of the mean ( \pm SD) metabolic rates of seagrass species in the Red Sea with their global average reported in Duarte et al. (2010).

\begin{tabular}{|c|c|c|c|c|c|c|}
\hline Species & Source & $\begin{array}{l}\text { GPP (mmol } \\
\left.\mathrm{O}_{2} \mathrm{~m}^{-2} \mathrm{~d}^{-1}\right)\end{array}$ & $\begin{array}{c}R(\mathrm{mmol} \\
\left.\mathrm{O}_{2} \mathrm{~m}^{-2} \mathrm{~d}^{-1}\right)\end{array}$ & $\begin{array}{l}\mathrm{NCP}(\mathrm{mmol} \\
\left.\mathrm{O}_{2} \mathrm{~m}^{-2} \mathrm{~d}^{-1}\right)\end{array}$ & GPP/R & 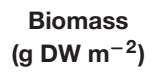 \\
\hline \multirow[t]{3}{*}{ Halodule uninervis } & This study (Red Sea) & $136 \pm 62$ & $49 \pm 49$ & $58 \pm 31$ & $2 \pm 0.53$ & $12 \pm 8$ \\
\hline & Duarte et al., 2010 (Tropical Australia) & $281 \pm 44$ & $231 \pm 97$ & $50 \pm 53$ & $1.4 \pm 0.58$ & $89 \pm 66$ \\
\hline & Duarte et al., 2010 (Tropical SE Asia) & $285 \pm 48$ & & & & $221 \pm 102$ \\
\hline \multirow[t]{2}{*}{ Halophila ovalis } & This study (Red Sea) & $85 \pm 26$ & $35 \pm 18$ & $50 \pm 17$ & $2.7 \pm 0.99$ & $4 \pm 1.3$ \\
\hline & Duarte et al., 2010 (Tropical SE Asia) & 270 & & & & 21 \\
\hline Halophila stipulacea & This study (Red Sea) & $121 \pm 72$ & $72 \pm 61$ & $52 \pm 25$ & $2.1 \pm 0.74$ & $15 \pm 10$ \\
\hline \multirow[t]{4}{*}{ Thalassia hemprichii } & This study (Red Sea) & $108 \pm 43$ & $61 \pm 26$ & $47 \pm 28$ & $1.9 \pm 0.68$ & $34 \pm 21$ \\
\hline & Duarte et al., 2010 (Tropical Australia) & $483 \pm 178$ & $414 \pm 180$ & $69 \pm 51$ & $1.18 \pm 0.15$ & $64 \pm 49$ \\
\hline & Duarte et al., 2010 (Tropical Indian) & 997 & 513 & 484 & 1.94 & \\
\hline & Duarte et al., 2010 (Tropical SE Asia) & $237 \pm 87$ & $271 \pm 164$ & $(-) 69 \pm 123$ & $0.9 \pm 0.3$ & $168 \pm 100$ \\
\hline Thalassodendron ciliatum & This study (Red Sea) & $141 \pm 60$ & $33 \pm 33$ & $51 \pm 45$ & $1.6 \pm 0.5$ & $63.4 \pm 18$ \\
\hline
\end{tabular}

species (H. uninervis and H. ovalis) we only had data to estimate the rising phase of the curve.

\section{Nutrient Concentration ( $N, P$, and $\mathrm{Fe}$ ) in Seagrass Leaves}

To assess potential nutrient limitation on the metabolic rates of seagrass meadows across seasons in the Red Sea, nutrient $(\mathrm{N}, \mathrm{P}$, and $\mathrm{Fe})$ concentrations were analyzed in seagrass leaves collected from shoots around sites where the cores (see above) were extracted. For small species of seagrasses (H. uninervis, $H$. ovalis, and H. stipulacea), we collected four shoots per replicate. For the larger species ( $T$. hemprichii), we collected the second youngest leaf, typically free of visible epiphytes, from four shoots for each replicate. Leaves were dried at $60^{\circ} \mathrm{C}$ and ground to a fine powder using an agate mortar and pestle. Elemental $\mathrm{N}$ content analyses of seagrass-leaf samples were performed using an Organic Elemental Analyzer Flash 200 (Thermo Fisher Scientific, MA, United States). The P and Fe concentrations of the seagrass leaves were determined by Inductively Coupled PlasmaOptical Emission Spectrometry [Varian Inc. model 720-ES; see Anton et al. (2018) for further details]. Concentrations of N and $\mathrm{P}$ were presented as $\%$ and $\mathrm{Fe}$ as $\mathrm{mg} \mathrm{kg}^{-1} \mathrm{DW}$ to allow direct comparisons with available literature describing nutrient limitation on seagrasses (Duarte, 1990; Duarte et al., 1995). We were not able to analyze all nutrients in all the locations and species (see Supplementary Table S2 for number of replicates per variable and location and seagrass species) because for some locations there was not enough seagrass tissue to run the analyses.

\section{Statistical Analysis}

Temperature and latitude were tested as drivers in the variability of metabolic rates of seagrass meadows (GPP, R, and NCP) and GPP/R ratio for each dominant species. Linear regressions or non-linear models (e.g., a Sharpe-Schoolfield curve) were used to analyze the relationship between temperature and metabolic rates, because relationships was either linear (e.g., increasing) or a unimodal curve. Generalized linear models (GLMs) were used to assess the effect of latitude on metabolic rates of three meadow-forming seagrass species
(H. uninervis, H. stipulacea, and T. hemprichii), but the data were only analyzed for the summer, because there was not enough data for the winter surveys. Similarly, GLMs were used to quantify the effect of latitude on the differential concentrations of $\% \mathrm{~N}, \% \mathrm{P}$, and $\mathrm{Fe}\left(\mathrm{mg} \mathrm{kg}^{-1} \mathrm{DW}\right)$ for seagrass leaves. In all the models, the response variable was calculated as the mean value per species per location to ensure statistical robustness.

\section{RESULTS}

Red Sea seagrass meadows had an aboveground biomass (mean $\pm \mathrm{SD}$ ) of $4 \pm 1,12 \pm 8,15 \pm 10,34 \pm 21$, and $63 \pm 18$ for $H$. ovalis, $H$. uninervis, H. stipulacea, T. hemprichii, and T. ciliatum, respectively (Table 1). The mean GPP and $\mathrm{R}$ rates ranged from $85 \pm 26$ ( H. ovalis) to $136 \pm 62$ (H. uninervis), and from $33 \pm 33$ (T. ciliatum) to $72 \pm 61$ (H. stipulacea) mmol $\mathrm{O}_{2} \mathrm{~m}^{-2} \mathrm{~d}^{-1}$, respectively (Table 1). The mean NCP of Red Sea seagrass meadows ranged from $47 \pm 28$ (T. hemprichii) to $58 \pm 31$ (H. uninervis) $\mathrm{mmol}$ $\mathrm{O}_{2} \mathrm{~m}^{-2} \mathrm{~d}^{-1}$, with all meadows being autotrophic (GPP/R > 1) on average (Table 1).

Thermal performance curves for meadows dominated by two species of seagrasses (H. stipulacea and T. hemprichii) revealed an optimum temperature $\left(T_{o p t}\right)$ of 30.59 and $30.89^{\circ} \mathrm{C}$ for $\mathrm{GPP}, 29.71$ and $29.78^{\circ} \mathrm{C}$ for $\mathrm{R}$, and 29.88 and $30.78^{\circ} \mathrm{C}$ for NCP, respectively (Figure 3 and Supplementary Table S3). Data obtained for $H$. uninervis and $H$. ovalis allowed us to capture only the rising phase of the thermal curve, with apparent optimum temperature at $\geq 31.5$ and $\geq 32^{\circ} \mathrm{C}$ for GPP and NCP, respectively (Figure 3 and Supplementary Table S3).

There was no relationship between latitude and summer metabolic rates (GPP, R, NCP, and GPP/R ratio), except for the GPP rates of $H$. uninervis meadows, which increased toward the south during the summer (Figure 4). Likewise, we did not find an effect of latitude on the nutrient concentration of leaves for three meadow-forming seagrass species (H. uninervis, $H$. stipulacea, and T. hemprichii; Figure 5). Mean $( \pm \mathrm{SD}) \% \mathrm{~N}, \% \mathrm{P}$, and $\mathrm{Fe}$ concentration (mg Fe kg DW ${ }^{-1}$ ) for seagrasses in the Red Sea 


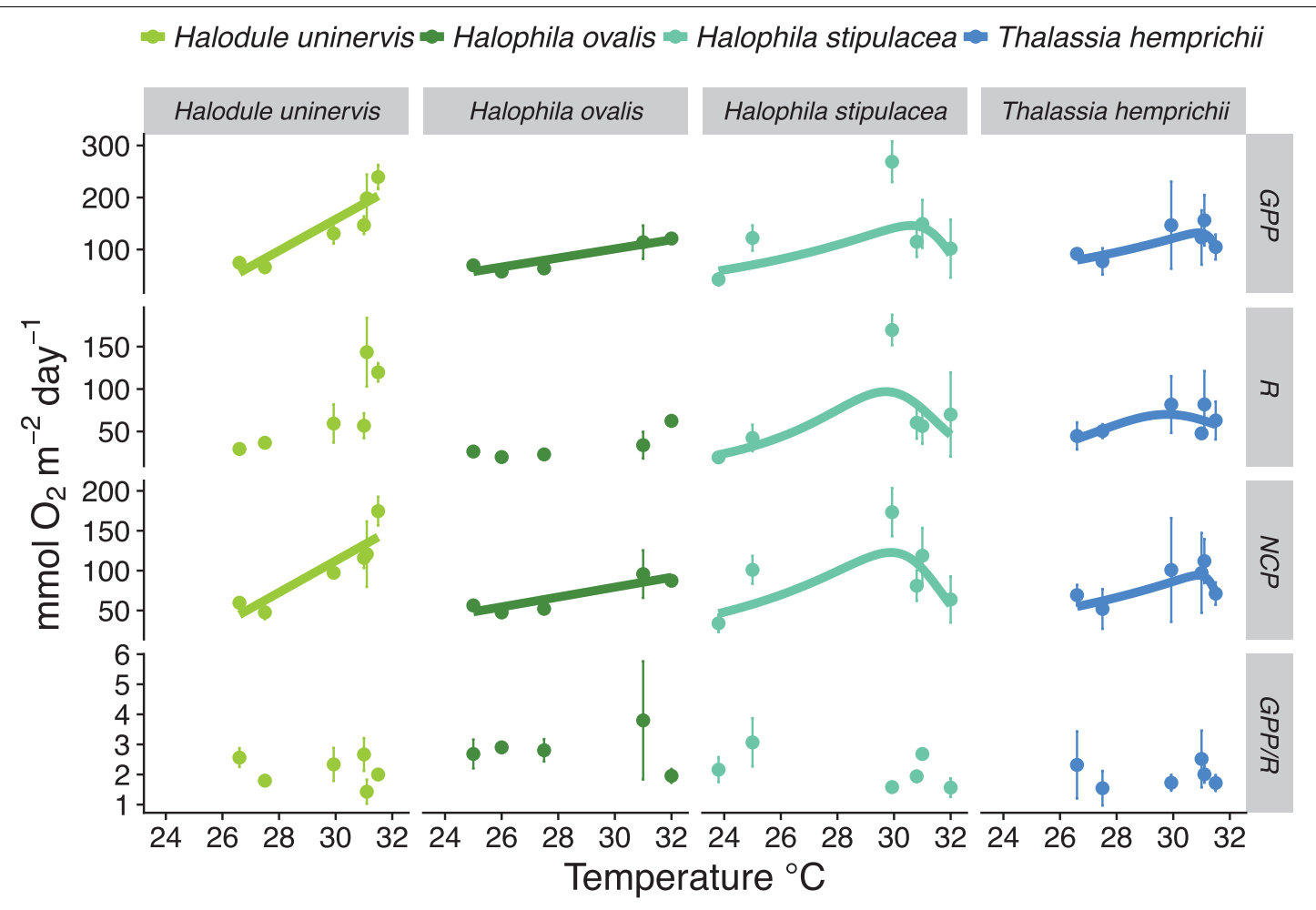

FIGURE 3 | Relationship between the temperature and the metabolic rates (GPP, R, and NCP in mmol $\mathrm{O}_{2} \mathrm{~m}^{-2} \mathrm{~d}^{-1}$ ) and GPP/R of seagrass meadows in the Red Sea. Colors indicate the dominant seagrass species on the meadows (Halodule uninervis in light green, Halophila ovalis in dark green, Halophila stipulacea in light blue, and Thalassia hemprichii in indigo blue). Solid dots indicate the mean \pm SD per location. Significant relationships are indicated with a solid line. Data collected in summer and winter are included.

was $2.43 \pm 0.57,0.18 \pm 0.05$, and $438 \pm 515$, respectively (Supplementary Table S2).

\section{DISCUSSION}

\section{Thermal Performance of Seagrass Meadows in the Red Sea}

Our results show differential thermal performance among meadows dominated by one of four species of seagrass along a latitudinal gradient. Meadows dominated by either $H$. uninervis or $H$. ovalis were the most thermophilic, with optimum temperatures exceeding current summer temperatures in the southern Red Sea (Chaidez et al., 2017). In fact, the highest GPP rate in our study $\left(215 \mathrm{mmol}\right.$ of $\left.\mathrm{O}_{2} \mathrm{~m}^{-2} \mathrm{~d}^{-1}\right)$ was recorded for $H$. uninervis in the lowest latitude during the summer $\left(18.3^{\circ} \mathrm{N}\right)$. This finding supports the contention that the seagrass genus Halodule ranks among the most thermophilic in the world (McMillan, 1984; Collier et al., 2011). The optimum temperature for the metabolic rates of T. hemprichii was between 29.8 and $30.9^{\circ} \mathrm{C}$, while H. stipulacea had a thermal optimum between 29.7 and $30.6^{\circ} \mathrm{C}$ across meadows. Our results suggest that the optimum temperature of Red Sea seagrass meadows increases along the sequence: $H$. stipulacea $<T$. hemprichii $<H$. uninervis $\sim H$. ovalis, generally supporting previous findings of thermal performance for seagrass species (McMillan, 1984; Collier et al., 2011). However, we found $H$. ovalis to be more tolerant to thermal stress than T. hemprichii, which contradicts previous experimental findings (Ralph, 1998; Campbell et al., 2006; Collier and Waycott, 2014). These differences might arise from differential experimental designs. Our measurements were holistic and performed at the meadow level. We included local sediment and biota (i.e., epiphytes) associated with the meadow, while previous experiments assessed physiological performance at the seagrass level (i.e., incubations of just the plant). Thermal inhibition of metabolic performance has been shown for other organisms in the southern Red Sea during the summer (e.g., primary production and calcification on corals; Sawall et al., 2015). We also document thermal inhibition in seagrass meadows of $H$. stipulacea and T. hemprichii in the southern region of Red Sea during the summer months - as indicated by a decrease in metabolic performance once passed the optimum temperature. The Red Sea is the warmest sea in the world and is currently warming at a rate almost twice the global average (Chaidez et al., 2017). However, the optimum temperature for the metabolic functions reported here falls within the global range for tropical seagrass species of $27-33^{\circ} \mathrm{C}$ (Koch et al., 2013).

Respiration rates in Red Sea seagrass meadows were generally low compared to global estimates (e.g., on average about five times lower than reported values for $H$. uninervis and T. hemprichii globally; Duarte et al., 2010), despite the elevated 


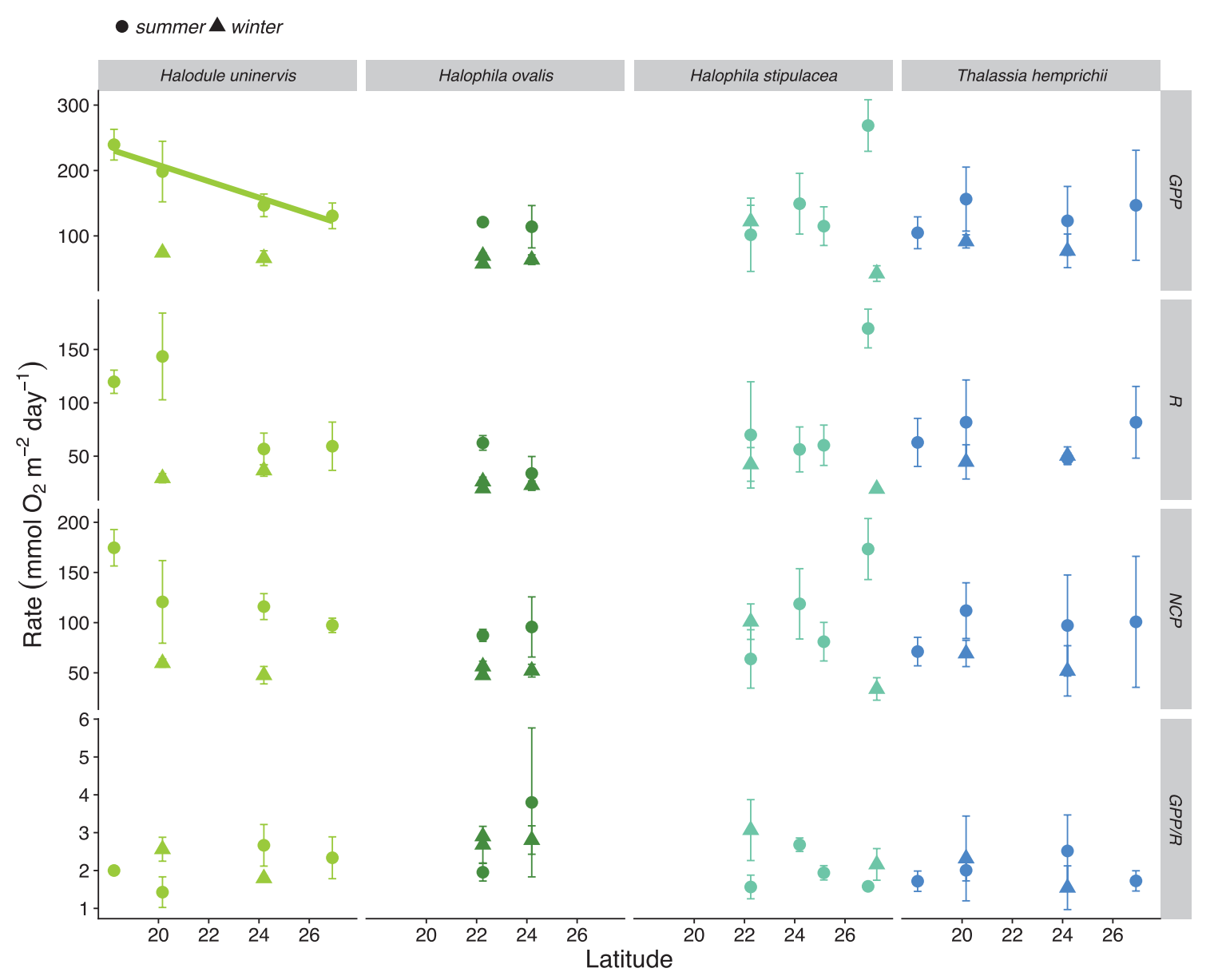

FIGURE 4 | Metabolic rates of seagrass meadows along a latitudinal gradient in the Red Sea. Gross primary production (GPP), respiration (R), and net community production (NCP) are presented in mmol of $\mathrm{O}_{2} \mathrm{~m}^{-2} \mathrm{~d}^{-1}$. Colors indicate the dominant seagrass species of the meadows (Halodule uninervis in light green, Halophila ovalis in dark green, Halophila stipulacea in light blue, and Thalassia hemprichii in indigo blue). Solid dots and triangles indicate the mean \pm SD per location in the summer and winter, respectively. Significant relationships are indicated with a solid line. Statistical results provided on Supplementary Table S4.

temperatures achieved during the summer. However, comparable low $\mathrm{R}$ rates were recently reported for pelagic food webs within the Red Sea (López-Sandoval et al., 2019). The low $\mathrm{R}$ rates observed for seagrass meadows in the Red Sea could provide a mechanism to cope with thermal stress during high temperature peaks common in shallow water environments during the summer (Tanaka and Nakaoka, 2007). This could also explain why we found a prevalence of autotrophic seagrass meadows in the Red Sea. Our results align with a recent report of also generalized autotrophic production in planktonic communities in the Red Sea (López-Sandoval et al., 2019).

Our results suggest that the optimum temperature of Red Sea seagrass meadows differs among dominant species within locations. This indicates that there are potential variable responses among seagrass species to ocean warming within meadows. Meadows of $H$. uninervis and $H$. ovalis will likely be resistant to moderate future warming, and perhaps benefit from it initially. On the other hand, meadows of $H$. stipulacea and T. hemprichii might become less productive with ongoing and future projections of warming for the next few decades.
This raises considerable concerns because these two seagrass species form extensive meadows throughout the Red Sea, with T. hemprichii contributing large standing stocks to above-ground seagrass biomass. In addition, meadows of these two species have been shown to provide important ecosystem services, such as the provision of food and shelter to higher tropic levels like fish and turtles (Khalaf et al., 2012; Kelkar et al., 2013, 2015).

\section{Metabolic Rates of Seagrass Meadows in the Red Sea Compared to Other Locations}

Red Sea seagrass meadows are relatively sparse, with the above ground biomass falling outside the lower range reported for the same species in other tropical regions (Duarte et al., 2010). Similarly, metabolic rates of seagrass meadows in the Red Sea were low when compared with the same species in other tropical locations. Specifically, GPP and R rates for Red Sea seagrass meadows of $H$. uninervis and T. hemprichii in this study were below the global range (mean $\pm \mathrm{SD}$ ), with the exception of GPP 


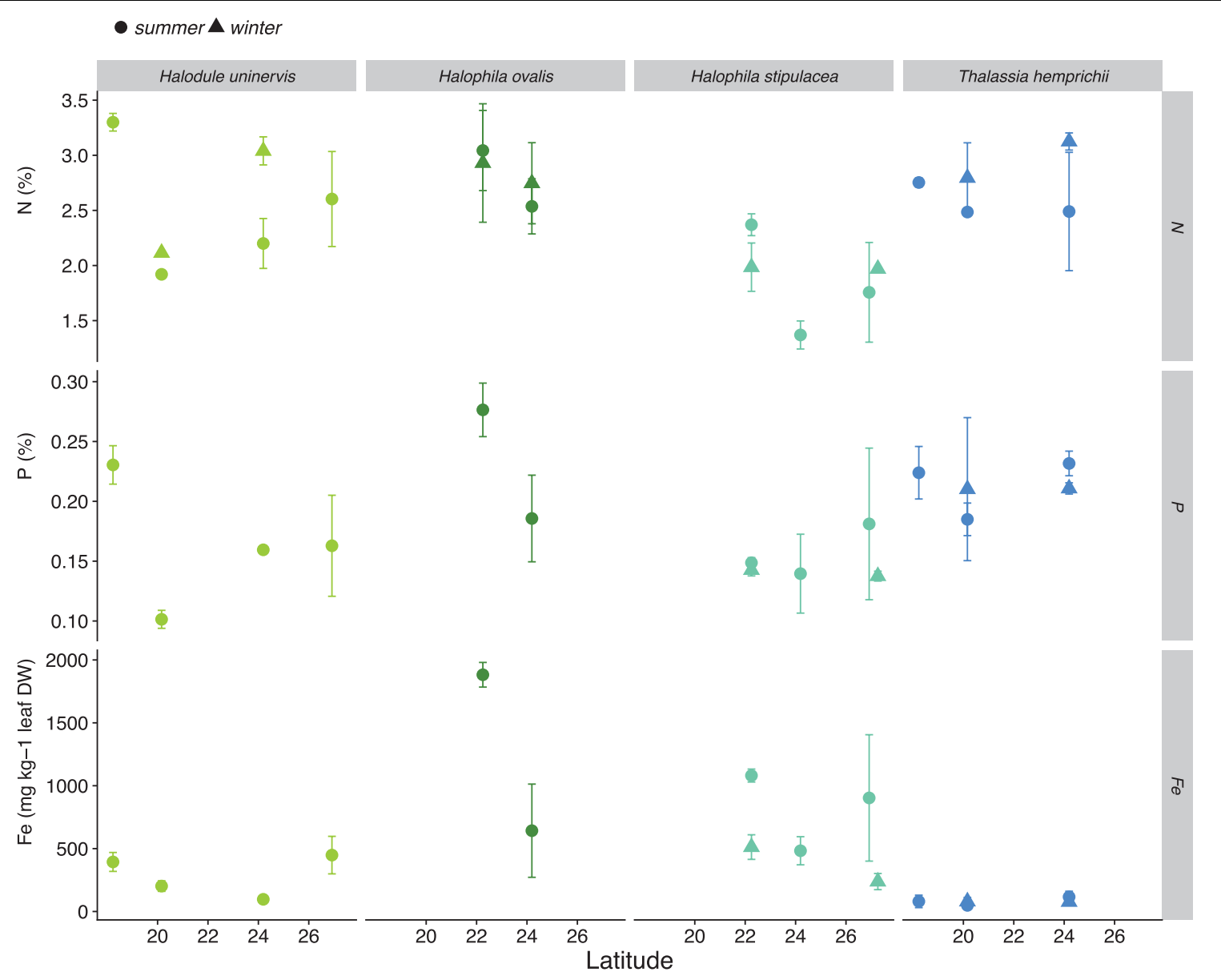

FIGURE 5 | Nutrient concentration (\%N, \%P, and [Fe] in $\left.\mathrm{mg} \mathrm{kg}^{-1} \mathrm{DW}\right)$ in the leaves of five species of seagrasses across the Red Sea. Colors indicate the dominant seagrass species on the meadows (Halodule uninervis in light green, Halophila ovalis in dark green, Halophila stipulacea in light blue, and Thalassia hemprichii in indigo blue). Solid dots and triangles indicate the mean \pm SD per location in the summer and winter of 2017, respectively. Statistical results provided on Supplementary Table S5.

for T. hemprichii that fell within the lower range of reported meadows in South East Asia (Duarte et al., 2010). NCP rates of H. uninervis and T. hemprichii meadows were within the range of values reported in the tropical Indo-Pacific (Duarte et al., 2010). This consistently positive NCP rates and $>1$ GPP/R ratio of seagrasses in the Red Sea are indicative of autotrophic ecosystems that act as carbon sinks. This was surprising as five species of seagrasses in the Central Red Sea (T. hemprichii, E. acoroides, $H$. stipulacea, T. ciliatum, and $H$. uninervis) were reported to be in the lower range of the organic carbon sink capacity of seagrasses (Serrano et al., 2018), for which NCP can be used as a proxy. The mean ratio between GPP and $\mathrm{R}$ for $H$. uninervis and $T$. hemprichii meadows in the Red Sea were within the range, but about two times larger than the global mean values reported for these tropical seagrasses elsewhere (Duarte et al., 2010). This further supports the potential capacity of Red Sea seagrass meadows to accumulate organic carbon in sediments. Although GPP/R ratio was high; meadow GPP rates for most of the seagrass locations were below the estimated threshold of $186 \mathrm{mmol} \mathrm{O}_{2} \mathrm{~m}^{-2} \mathrm{~d}^{-1}$, above which seagrass communities have been hypothesized to act as $\mathrm{CO}_{2}$ sinks $(\mathrm{GPP} / \mathrm{R}>1$, Duarte et al., 2010).

Our metabolic rates for $H$. uninervis meadows diverge from those recently reported for a mixed meadow of $H$. uninervis and C. serrulata in the central Red Sea (Burkholz et al., 2019). Their reported GPP and $\mathrm{R}$ rates were two and five times higher than what we recorded for mono-specific meadows of H. uninervis. Furthermore, NCP rates and GPP/R ratios were about nine and two times higher than in our study. The differences among studies might result from the difference in standing stock above ground biomass among meadows, which was about 20 times higher in the mixed meadow (average $269 \mathrm{~g} \mathrm{DW} \mathrm{m} \mathrm{m}^{-2}$; Burkholz et al., 2019) than in our mono-specific meadows (average $12 \mathrm{~g} \mathrm{DW} \mathrm{m}^{-2}$ ). This large difference in biomass could derive from several factors such as (i) mixed meadows achieve higher above ground biomass than the mono-specific meadows of the same species (Duarte et al., 2010), (ii) we removed the epiphytes on the leaves which can achieve substantial biomass loads (Nelson, 2017), but Burkholz et al. (2019) did not, (iii) differences 
in depth/light availability $(0.5-5 \mathrm{~m}$ in our study and $0.7 \mathrm{~m}$ in Burkholz et al., 2019), and (iv) potential differences in sediment composition.

\section{Latitudinal Effects}

The latitudinal effects on seagrass metabolic rates were speciesspecific, with $H$. uninervis meadows displaying a strong latitudinal pattern with GPP increasing toward the south during the summer. We did not find any latitudinal patterns for metabolic rates of $T$. hemprichii and $H$. stipulacea during the summer, suggesting possible regional acclimation in meadows of these species in the Red Sea. A similar finding was reported in the Red Sea for the ubiquitous coral P. verrucosa (Sawall et al., 2015). Additionally, a lack of latitudinal patters were recently reported along the Red Sea for productivity of two macrophytes (the seagrass H. stipulacea and the macroalgae Turbinaria ornata) (Anton et al., 2018).

\section{$\mathrm{P}$ and Fe Limitation}

No latitudinal pattern was found for nutrient concentrations $(\mathrm{N}, \mathrm{P}$, and $\mathrm{Fe}$ ) in seagrass leaves along the Red Sea. However, the low nutrient concentration recorded suggest that seagrass meadows in the Red Sea might be limited by the availability of $\mathrm{P}$ and $\mathrm{Fe}$, since $\% \mathrm{P}$ and the $\mathrm{Fe}$ concentration $\left(\mathrm{mg} \mathrm{kg}^{-1}\right)$

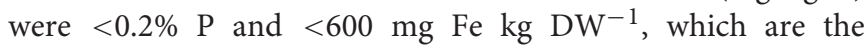
thresholds for $\mathrm{P}$ and Fe sufficiency reported in seagrasses (Duarte, 1990; Duarte et al., 1995). In carbonate-rich sediments, such as those associated with seagrasses in the Red Sea (Garcias-Bonet et al., 2019), $\mathrm{P}$ and Fe are often bound in unavailable forms (Ruiz-Halpern et al., 2008). Within the rhizosphere, tropical seagrasses appear to mobilize $\mathrm{P}$ and Fe via plant-induced local acidification (Long et al., 2008; Brodersen et al., 2017), leading to concomitant $\mathrm{P}$ and $\mathrm{Fe}$ release into the sediment porewater. To our knowledge, this study is the first documentation of potential P limitation on seagrasses in the Red Sea, although it has been reported on other comparable seagrass meadows in the Mediterranean Sea, Caribbean, and Coral Triangle (Perez et al., 1991; Agawin et al., 1996). Low iron concentrations $\left(<600 \mathrm{mg} \mathrm{Fe} \mathrm{kg} \mathrm{DW}^{-1}\right)$ in the leaves of seagrasses were recently reported in the Red Sea (Anton et al., 2018), with two species, $T$. hemprichii and $T$. ciliatum, showing an $\mathrm{Fe}$ concentration below the critical threshold for seagrasses ( $<100 \mathrm{mg}$ Fe $\mathrm{kg}$ $\mathrm{DW}^{-1}$; Duarte et al., 1995), which is consistent with our current findings. Similarly, Fe-limitation on seagrasses has been shown on other tropical locations with carbonate-rich sediments (Duarte et al., 1995). In the arid Red Sea, the lack of river inputs associates with low $\mathrm{P}$ and $\mathrm{Fe}$ inputs, with the main nutrient sources being inputs of water from the Indian Ocean in the south via the Strait of Bab al Mandab (Triantafyllou et al., 2014) and dust deposition (Jish Prakash et al., 2015). Seagrasses in the Red Sea are likely to not experience $\mathrm{N}$ limitation, as the concentration in the leaves was $>2 \%$, the reported threshold for $\mathrm{N}$ sufficiency in seagrasses (Duarte, 1990). Nitrogen fixation has been proposed as the main source of $\mathrm{N}$ for seagrasses in Red Sea, specially in the northern oligotrophic region (Duarte et al., 2018).

\section{Study Limitations}

Several potential limitations arose from this study. The limited data available for $H$. ovalis and T. ciliatum meadows - due to limited knowledge on the local distribution of seagrass meadows before the surveys and logistical constrains during the trips precluded the analysis of metabolic rates along the latitudinal gradient. Depth is an important driver of seagrass metabolism, mainly because it affects the light reaching the plants (Dennison, 1987; Hemminga and Duarte, 2000). The meadows sampled in this study were located at depths ranging between 0.5 and $7 \mathrm{~m}$. However, with the exception of two locations (sites S1 and S2 in Duba at 7 and $5 \mathrm{~m}$ depth, respectively), seagrass meadows were $<3 \mathrm{~m}$ in depth. This is likely a reasonable depth range to perform comparisons across locations with the largest depthdifference among meadows, with the same dominant species between site S2 (at $5 \mathrm{~m}$ ) and S7 $(0.5 \mathrm{~m})$, which had H. uninervis and T. hemprichii as dominant species. When specifically looking at a potential effect of depth-difference for these meadows, we found contrasting effects for the species: T. hemprichii meadows increased in mean productivity with increasing depth (mean GPP in Farasan Banks at $0.5 \mathrm{~m}$ and Duba at $5 \mathrm{~m}$ were 98 and $131 \mathrm{mmol} \mathrm{O}_{2} \mathrm{~m}^{-2} \mathrm{~d}^{-1}$, respectively) while the mean productivity of $H$. uninervis meadows decreased with depth (mean GPP in Farasan Banks at $0.5 \mathrm{~m}$ and Duba at $5 \mathrm{~m}$ were 221 and $117 \mathrm{mmol}$ $\mathrm{O}_{2} \mathrm{~m}^{-2} \mathrm{~d}^{-1}$, respectively; Figure 3 ). Therefore, there is not a clear pattern with depth-difference across sites and species, suggesting that additional factors (e.g., latitude or local nutrient availability) may contribute to variation in the metabolic rates of seagrass meadows in the Red Sea. Finally, the water inside the cores was not mixed during incubations so as not to stir up the fine sediment and alter the turbidity of the water. This has the potential to introduce inaccuracy into the metabolic rate calculations and can led to an underestimation of the photosynthesis rates (Beer et al., 2001).

\section{CONCLUSION}

This is the first report of metabolic rates of seagrasses across a broad latitudinal range in the Red Sea. Our data reveal comparatively low community metabolic rates of Red Sea seagrasses compared to tropical seagrass meadows of the same species elsewhere. These measurements at a broad spatial range improve our understanding into the ecological drivers of productivity in tropical seagrasses, for which temperature was identified as strong predictor in this warm and oligotrophic location. Earlier efforts at assessing seagrass metabolism (Duarte et al., 2010) reported geographic imbalances in the spread of the data available. Our results help address this gap for the Red Sea, a poorly explored biodiversity hot-spot for seagrasses (El Shaffai, 2011).

\section{DATA AVAILABILITY STATEMENT}

The data set used for this manuscript is provided in Supplementary Table S2. 


\section{AUTHOR CONTRIBUTIONS}

$\mathrm{AA}$ and $\mathrm{CD}$ conceived the project. $\mathrm{AA}, \mathrm{DC}$, and $\mathrm{KB}$ performed the research. AA analyzed the data and wrote the first draft of the manuscript. All authors contributed to interpreting the results, writing, and approved the submission.

\section{FUNDING}

This research was funded by the King Abdullah University of Science and Technology (KAUST) through baseline funding and center associated research and competitive funding allocated to CMD and Center Competitive Funding (CCF) grant number FCC/1/1973-21-01 to the Red Sea Research Center.

\section{REFERENCES}

Agawin, N. S. R., Duarte, C. M., and Fortes, M. D. (1996). Nutrient limitation of philippine seagrasses (cape bolinao, NW Philippines): in situ experimental evidence. Mar. Ecol. Prog. Ser. 138, 233-243. doi: 10.3354/meps138233

Almahasheer, H., Duarte, C. M., and Irigoien, X. (2016). Nutrient limitation in central Red Sea mangroves. Front. Mar. Sci. 3:271. doi: 10.3389/fmars.2016. 00271

Anton, A., Cebrian, J., Duarte, C. M., Heck, K. L., and Goff, J. (2009). Low impact of hurricane Katrina on seagrass community structure and functioning in the northern gulf of mexico. Bull. Mar. Sci. 85, 45-59.

Anton, A., Cebrian, J., Heck, K. L., Duarte, C. M., Sheehan, K. L., Miller, M.-E. C., et al. (2011). Decoupled effects (positive to negative) of nutrient enrichment on ecosystem services. Ecol. Appl. 21, 991-1009. doi: 10.1890/09-0841.1

Anton, A., Hendriks, I. E., Marbà, N., Krause-Jensen, D., Garcias-Bonet, N., and Duarte, C. M. (2018). Iron deficiency in seagrasses and macroalgae in the Red Sea is unrelated to latitude and physiological performance. Front. Mar. Sci. 5:74. doi: 10.3389/fmars.2018.00074

Bednarz, V. N., Hoytema, N., van Cardini, U., Naumann, M. S., Al-Rshaidat, M. M. D., and Wild, C. (2015). Dinitrogen fixation and primary productivity by carbonate and silicate reef sand communities of the Northern Red Sea. Mar. Ecol. Prog. Ser. 527, 47-57. doi: 10.3354/meps11224

Beer, S., Bjork, M., Gademann, R., and Ralph, P. J. (2001). "Measurements of Photosynthetic Rates in Seagrasses," in Global Seagrass Research Methods. Netherlands: Elsevier Publishing.

Brodersen, K. E., Koren, K., Moßhammer, M., Ralph, P. J., Kühl, M., and Santner, J. (2017). Seagrass-mediated phosphorus and iron solubilization in tropical sediments. Environ. Sci. Technol. 51, 14155-14163. doi: 10.1021/acs.est. $7 \mathrm{~b} 03878$

Burkholz, C., Duarte, C. M., and Garcias-Bonet, N. (2019). Thermal dependence of seagrass ecosystem metabolism in the Red Sea. Mar. Ecol. Prog. Ser. 614, 79-90. doi: 10.3354/meps 12912

Campbell, S. J., McKenzie, L. J., and Kerville, S. P. (2006). Photosynthetic responses of seven tropical seagrasses to elevated seawater temperature. J. Exp. Mar. Biol. Ecol. 330, 455-468. doi: 10.1016/j.jembe.2005.09.017

Cardini, U., Hoytema, N., van Bednarz, V. N., Al-Rshaidat, M. M. D., and Wild, C. (2018). N2 fixation and primary productivity in a Red Sea Halophila stipulacea meadow exposed to seasonality. Limnol. Oceanogr. 63, 786-798. doi: 10.1002/ lno.10669

Chaidez, V., Dreano, D., Agusti, S., Duarte, C. M., and Hoteit, I. (2017). Decadal trends in Red Sea maximum surface temperature. Sci. Rep. 7:8144. doi: 10.1038/ s41598-017-08146-z

Collier, C. J., Uthicke, S., and Waycott, M. (2011). Thermal tolerance of two seagrass species at contrasting light levels: implications for future distribution in the great barrier reef. Limnol. Oceanogr. 56, 2200-2210. doi: 10.4319/lo.2011. 56.6.2200

\section{ACKNOWLEDGMENTS}

We thank Zenon Batang, Paul Muller, and Brian Hession for logistical support at CMOR, the crew from RV Thuwal for logistical support across the surveys, Nathan Geraldi, Amr Gusti, Tane Sinclair-Taylor, and Tullia Terraneo for their assistance in the field, and Mongi Ennasri, Vijayalaxmi Dasari, and Nadia Haj Salah for her assistance in the laboratory.

\section{SUPPLEMENTARY MATERIAL}

The Supplementary Material for this article can be found online at: https://www.frontiersin.org/articles/10.3389/fmars. 2020.00069/full\#supplementary-material

Collier, C. J., and Waycott, M. (2014). Temperature extremes reduce seagrass growth and induce mortality. Mar. Pollut. Bull. 83, 483-490. doi: 10.1016/j. marpolbul.2014.03.050

Dennison, W. C. (1987). Effects of light on seagrass photosynthesis, growth and depth distribution. Aquat. Bot. 27, 15-26. doi: 10.1016/0304-3770(87)9008390080

Duarte, C. M. (1990). Seagrass nutrient content. Marine Ecology Progress Series. 67, 201-207. doi: 10.3354/meps067201

Duarte, C. M., and Chiscano, C. L. (1999). Seagrass biomass and production: a reassessment. Aquat. Bot. 65, 159-174. doi: 10.1016/S0304-3770(99)00038-38

Duarte, C. M., Delgado-Huertas, A., Anton, A., Carrillo-de-Albornoz, P., LópezSandoval, D. C., Agustí, S., et al. (2018). Stable Isotope ( $\delta 13 \mathrm{C}, \delta 15 \mathrm{~N}, \delta 18 \mathrm{O}, \delta \mathrm{D})$ composition and nutrient concentration of Red Sea primary producers. Front. Mar. Sci. 5:298. doi: 10.3389/fmars.2018.00298

Duarte, C. M., Marba, N., Gacia, E., Fourqurean, J. W., Beggins, J., Barron, C., et al. (2010). Seagrass community metabolism: assessing the carbon sink capacity of seagrass meadows. Glob. Biogeochem. Cycles 24:GB4032. doi: 10. 1029/2010GB003793

Duarte, C. M., Merino, M., and Gallegos, M. (1995). Evidence of iron deficiency in seagrasses growing above carbonate sediments. Limnol. Oceanogr. 40, 11531158. doi: 10.4319/lo.1995.40.6.1153

El Shaffai, A. (2011). Field Guide to Seagrasses of the Red Sea. First Edition, eds A. Rouphael, and A. Abdulla, (Gland: IUCN and Total foundation).

Fourqurean, J. W., Duarte, C. M., Kennedy, H., Marbà, N., Holmer, M., Mateo, M. A., et al. (2012). Seagrass ecosystems as a globally significant carbon stock. Nat. Geosci. 5, 505-509. doi: 10.1038/ngeo1477

García, F. C., Bestion, E., Warfield, R., and Yvon-Durocher, G. (2018). Changes in temperature alter the relationship between biodiversity and ecosystem functioning. Proc. Natl. Acad. Sci. 115, 10989-10994. doi: 10.1073/pnas. 1805518115

Garcias-Bonet, N., Delgado-Huertas, A., Carrillo-de-Albornoz, P., Anton, A., Almahasheer, H., Marbà, N., et al. (2019). Carbon and nitrogen concentrations, stocks, and isotopic compositions in Red Sea seagrass and mangrove sediments. Front. Mar. Sci. 6:267. doi: 10.3389/fmars.2019.00267

Hemminga, M. A., and Duarte, C. M. (2000). Seagrass Ecology. Cambridge: Cambridge University Press.

Jish Prakash, P., Stenchikov, G., Kalenderski, S., Osipov, S., and Bangalath, H. (2015). The impact of dust storms on the Arabian Peninsula and the Red Sea. Atmospheric Chem. Phys. 15, 199-222. doi: 10.5194/acp-15-199-2015

Kelkar, N., Arthur, R., Marba, N., and Alcoverro, T. (2013). Green turtle herbivory dominates the fate of seagrass primary production in the Lakshadweep islands (Indian Ocean). Mar. Ecol. Prog. Ser. 485, 235-243. doi: 10.3354/meps1 0406

Kelkar, N., Arthur, R., Marbà, N., and Alcoverro, T. (2015). Greener pastures? highdensity feeding aggregations of green turtles precipitate species shifts in seagrass meadows. J. Ecol. 101, 1158-1168. doi: 10.1111/1365-2745.12122 
Khalaf, M. A., Al-Rousan, S., and Al-Horani, F. A. (2012). Fish assemblages in seagrass habitat along the Jordanian coast of the Gulf of Aqaba. Nat. Sci. 4, 517-525. doi: 10.4236/ns.2012.48069

Koch, M., Bowes, G., Ross, C., and Zhang, X.-H. (2013). Climate change and ocean acidification effects on seagrasses and marine macroalgae. Glob. Change Biol. 19, 103-132. doi: 10.1111/j.1365-2486.2012.02791.x

Long, M. H., McGlathery, K. J., Zieman, J. C., and Berg, P. (2008). The role of organic acid exudates in liberating phosphorus from seagrass-vegetated carbonate sediments. Limnol. Oceanogr. 53, 2616-2626. doi: 10.4319/lo.2008. 53.6.2616

López-Sandoval, D. C., Rowe, K., Carillo-de-Albonoz, P., Duarte, C. M., and Agustí, S. (2019). Rates and drivers of Red Sea plankton community metabolism. Biogeosciences 16, 2983-2995. doi: 10.5194/bg-16-2983-2019

Marbà, N., and Duarte, C. M. (2010). Mediterranean warming triggers seagrass (Posidonia oceanica) shoot mortality. Glob. Change Biol. 16, 2366-2375. doi: 10.1111/j.1365-2486.2009.02130.x

McMillan, C. (1984). The distribution of tropical seagrasses with relation to their tolerance of high temperatures. Aquat. Bot. 19, 369-379. doi: 10.1016/03043770(84)90049-90044

Nelson, W. G. (2017). Development of an epiphyte indicator of nutrient enrichment: a critical evaluation of observational and experimental studies. Ecol. Indic. 79, 207-227. doi: 10.1016/j.ecolind.2017.04.034

O'Connor, M. I., Piehler, M. F., Leech, D. M., Anton, A., and Bruno, J. F. (2009). Warming and resource availability shift food web structure and metabolism. PLoS Biol. 7:e1000178. doi: 10.1371/journal.pbio.1000178

Padfield, D., Lowe, C., Buckling, A., Ffrench-Constant, R., Jennings, S., Shelley, F., et al. (2017). Metabolic compensation constrains the temperature dependence of gross primary production. Ecol. Lett. 20, 1250-1260. doi: 10.1111/ele.12820

Pedersen, O., Colmer, T. D., Borum, J., Zavala-Perez, A., and Kendrick, G. A. (2016). Heat stress of two tropical seagrass species during low tides - impact on underwater net photosynthesis, dark respiration and diel in situ internal aeration. New Phytol. 210, 1207-1218. doi: 10.1111/nph.13900

Perez, M., Romero, J., Duarte, C. M., and Sand-Jensen, K. (1991). Phosphorus limitation of Cymodocea nodosa growth. Mar. Biol. 109, 129-133. doi: 10.1007/ BF01320239

Raitsos, D. E., Pradhan, Y., Brewin, R. J. W., Stenchikov, G., and Hoteit, I. (2013). Remote sensing the phytoplankton seasonal succession of the Red Sea. PLoS One 8:e64909. doi: 10.1371/journal.pone.0064909
Ralph, P. J. (1998). Photosynthetic response of laboratory-cultured Halophila ovalis to thermal stress. Mar. Ecol. Prog. Ser. 171, 123-130. doi: 10.3354/meps17 1123

Ruiz-Halpern, S., Macko, S. A., and Fourqurean, J. W. (2008). The effects of manipulation of sedimentary iron and organic matter on sediment biogeochemistry and seagrasses in a subtropical carbonate environment. Biogeochemistry 87, 113-126. doi: 10.1007/s10533-007-9162-9167

Sawall, Y., Al-Sofyani, A., Hohn, S., Banguera-Hinestroza, E., Voolstra, C. R., and Wahl, M. (2015). Extensive phenotypic plasticity of a Red Sea coral over a strong latitudinal temperature gradient suggests limited acclimatization potential to warming. Sci. Rep. 5:8940. doi: 10.1038/srep08940

Serrano, O., Almahasheer, H., Duarte, C. M., and Irigoien, X. (2018). Carbon stocks and accumulation rates in Red Sea seagrass meadows. Sci. Rep. 8:15037. doi: 10.1038/s41598-018-33182-33188

Sibly, R. M., Brown, J. H., and Kodric-Brown, A. (2012). Metabolic Ecology: A Scaling Approach. Hoboken, NJ: Wiley-Blackwell.

South, J., Welsh, D., Anton, A., Sigwart, J. D., and Dick, J. T. A. (2018). Increasing temperature decreases the predatory effect of the intertidal shanny Lipophrys pholis on an amphipod prey. J. Fish Biol. 92, 150-164. doi: 10.1111/jfb. 13500

Tanaka, Y., and Nakaoka, M. (2007). Interspecific variation in photosynthesis and respiration balance of three seagrasses in relation to light availability. Mar. Ecol. Prog. Ser. 350, 63-70. doi: 10.3354/meps07103

Triantafyllou, G., Yao, F., Petihakis, G., Tsiaras, K. P., Raitsos, D. E., and Hoteit, I. (2014). Exploring the Red Sea seasonal ecosystem functioning using a threedimensional biophysical model. J. Geophys. Res. Oceans 119, 1791-1811. doi: 10.1002/2013JC009641

Conflict of Interest: The authors declare that the research was conducted in the absence of any commercial or financial relationships that could be construed as a potential conflict of interest.

Copyright (c) 2020 Anton, Baldry, Coker and Duarte. This is an open-access article distributed under the terms of the Creative Commons Attribution License (CC BY). The use, distribution or reproduction in other forums is permitted, provided the original author(s) and the copyright owner(s) are credited and that the original publication in this journal is cited, in accordance with accepted academic practice. No use, distribution or reproduction is permitted which does not comply with these terms. 